https://journal.unfias.ac.id/indexpprp/jms//index

Vol. 18, No. 1, 12-21, September, 2021

DOI: $10.20956 /$ j.v18i1.13881

\title{
Dynamics Analysis of Modified Leslie-Gower Model with Simplified Holling Type IV Functional Response
}

\section{Analisis Dinamik Modifikasi Model Leslie-Gower dengan Fungsi Respon Holling Tipe IV yang Disederhanakan}

\author{
Nur Suci Ramadhani ${ }^{1 *}$, Syamsuddin Toaha $^{2 *}$, Kasbawati $^{3^{*}}$
}

\begin{abstract}
In this paper, modified Leslie-Gower predator-prey model with simplified Holling type IV functional response is discussed. It is assumed that the prey population is a dangerous population. The equilibrium point of the model and the stability of the coexistence equilibrium point are analyzed. The simulation results show that both prey and predator populations will not become extinct as time increases. When the prey population density increases, there is a decrease in the predatory population density because the dangerous prey population has a better ability to defend itself from predators when the number is large enough.
\end{abstract}

Keywords: Predator-Prey, Modified Leslie-Gower Model, Functional Response, Simplified Holling Type IV.

\begin{abstract}
Abstrak
Dalam tulisan ini dibahas modifikasi model mangsa pemangsa Leslie-Gower dan fungsi respon Holling tipe IV yang disederhanakan. Diasumsikan bahwa populasi mangsa adalah populasi yang berbahaya. Titik-titik kesetimbangan model dan kestabilan dari titik kesetimbangan koeksistensi dianalisis. Selanjutnya, dilakukan simulasi numerik di sekitar titik kesetimbangan koeksistensi. Hasil simulasi menunjukkan bahwa kedua populasi mangsa dan pemangsa tidak akan punah pada saat waktu semakin membesar. Pada saat kepadatan populasi mangsa meningkat terjadi penurunan terhadap kepadatan populasi pemangsa karena populasi mangsa yang berbahaya memiliki kemampuan yang lebih baik untuk mempertahankan diri dari pemangsa ketika jumlahnya cukup besar.
\end{abstract}

Kata kunci: Mangsa Pemangsa, Modifikasi model Leslie-Gower, Fungsi Respon, Holling Tipe IV yang disederhanakan.

* Program Studi Magister Matematika FMIPA-UNHAS

Email: nursuciramadhani97@gmail.com ${ }^{1}$,syamsuddint@yahoo.com ${ }^{2}$, kasbawati@gmail.com ${ }^{3}$

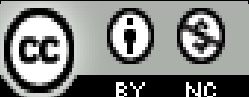

This work is licensed under a Creative Commons Attribution-NonCommercial 4.0 International License 


\section{Jurnal Matematika, Statistika \& Komputasi} Nur Suci Ramadhani, Syamsuddin Toaha, Kasbawati

\section{Pendahuluan}

Interaksi antar populasi dalam suatu lingkungan sangat kompleks. Banyak peneliti yang telah mempelajari dinamika antar populasi menggunakan model matematika. Model matematika dibangun berdasarkan pada data dan fenomena nyata [12]. Model tersebut dapat digunakan untuk menjelaskan perilaku fenomena alam yang terjadi, memprediksi perilaku sistem untuk suatu jangka waktu tertentu dan juga digunakan untuk mengambil suatu kebijakan [17]. Salah satu interaksi yang sering terjadi adalah interaksi antara populasi mangsa dan pemangsa. Model interaksi populasi mangsa pemangsa yang paling sering digunakan adalah model Lotka-Volterra. Model ini berasumsi bahwa tanpa adanya pemangsa maka populasi mangsa akan tumbuh secara eksponensial dan pertumbuhan pemangsa bergantung pada tangkapan mangsa. Selanjutnya, Leslie dan Gower memperkenalkan sebuah model sebagai modifikasi dari model Lotka-Volterra yang disebut sebagai model mangsa pemangsa Leslie-Gower dengan asumsi bahwa populasi yang berinteraksi tumbuh sesuai dengan pertumbuhan logistik yang menyatakan bahwa populasi tidak dapat tumbuh tanpa batas karena pertumbuhannya dipengaruhi oleh kepadatan populasi dan daya dukung lingkungan yang sifatnya terbatas serta daya dukung lingkungan untuk pemangsa tidak konstan tetapi proporsional dengan ukuran populasi mangsa [18].

Model mangsa pemangsa Leslie-Gower telah banyak digunakan untuk menggambarkan interaksi antara populasi mangsa dan pemangsa. Beberapa modifikasi pada model tersebut telah banyak dilakukan oleh peneliti sebelumnya, seperti Alaoui dan Okiye [1] melakukan modifikasi pada persamaan kedua dalam model umum Leslie-Gower atau pada persamaan populasi pemangsa dan menggunakan fungsi respon Holling tipe II untuk menggambarkan jumlah individu mangsa yang dimakan oleh pemangsa. Yu [18] menggunakan modifikasi model mangsa pemangsa Leslie-Gower yang dikemukakan dalam penelitian [1] dan menggunakan fungsi respon Beddington-DeAngelis. Beberapa modifikasi lainnya dapat dilihat dalam $[2,4,5,9,13,14,16$, 19].

Dalam dinamika populasi mangsa pemangsa, pertahanan kelompok adalah istilah yang digunakan untuk menggambarkan fenomena ketika predasi berkurang atau bahkan dicegah sama sekali karena peningkatan kemampuan mangsa yang lebih baik dalam mempertahankan atau menyamarkan diri ketika jumlah mangsa cukup besar. Untuk menggambarkan fenomena ini, fungsi respon yang digunakan untuk menggambarkan interaksi mangsa dan pemangsa adalah fungsi respon Holling tipe IV yang disederhanakan [11]. Andrews [3] memperkenalkan fungsi respon Holling tipe IV dalam bentuk $P_{1}(x)=\frac{m x}{a+b x+x^{2}}$ dan biasa disebut sebagai fungsi respon Monod-Haldane. Selanjutnya, pada tahun 1981 Sokol dan Howell [13] mengusulkan bentuk sederhana dari fungsi respon Monod-Haldane dan menemukan bahwa fungsi tersebut lebih sederhana dan lebih sesuai dengan data eksperimen yang digunakan secara signifikan dalam penelitiannya tentang kinetika oksidasi phenol. Fungsi tersebut dituliskan dalam bentuk $P_{2}(x)=\frac{m x}{a+x^{2}}$. Dalam dinamika populasi fungsi respon Holling tipe IV digunakan untuk menggambarkan perilaku dari populasi mangsa yang berbahaya karena mangsa yang berbahaya memiliki kemampuan yang lebih baik dalam mempertahankan atau menyamarkan diri dari pemangsa ketika jumlahnya cukup besar sehingga pada saat kepadatan mangsa meningkat maka daya predasi dari pemangsa berkurang.

Penelitian yang berkaitan dengan fungsi respon Holling tipe IV yang disederhanakan dalam model mangsa pemangsa telah banyak dilakukan oleh peneliti, seperti Ruan dan Xiao [10] melakukan analisis global pada sistem mangsa pemangsa Lotka-Volterra menggunakan fungsi respon Holling tipe IV yang disederhanakan. Penelitian selanjutnya, Huang [6] melakukan 


\section{Jurnal Matematika, Statistika \& Komputasi}

\section{Nur Suci Ramadhani, Syamsuddin Toaha, Kasbawati}

analisis bifurkasi pada model Leslie-Gower dengan pertumbuhan logistik pada mangsa dan menggunakan fungsi respon Holling tipe IV yang disederhanakan. Huang, T., dkk [7] melakukan analisis pembentukan pola terhadap model Lotka-Volterra dengan fungsi respon Holling tipe IV yang disederhanakan. Khajanchi [8] melakukan analisis pada sistem mangsa pemangsa tahapan struktur dengan fungsi respon Holling tipe IV yang disederhanakan.

Berdasarkan beberapa penelitian sebelumnya, peneliti akan mengkaji perilaku dari kedua populasi mangsa dan pemangsa ketika mangsa yang tersedia adalah populasi mangsa yang berbahaya. Adapun model yang digunakan dalam penelitian ini merupakan modifikasi model Leslie-Gower pada persamaan populasi pemangsa yang dikemukakan dalam penelitian Alaoui dan Okiye [1] dan menggunakan bentuk sederhana dari fungsi respon Holling tipe IV untuk menggambarkan interaksi antara populasi mangsa dan pemangsa.

\section{Pembentukan Model}

Model mangsa pemangsa yang digunakan dalam penelitian ini dikembangkan dari penelitian Alaoui dan Okiye [1] yang terdiri atas mangsa $(u)$ yang merupakan makanan untuk pemangsa $(v)$ yang hubungannya dapat dilihat pada Gambar 2.1.

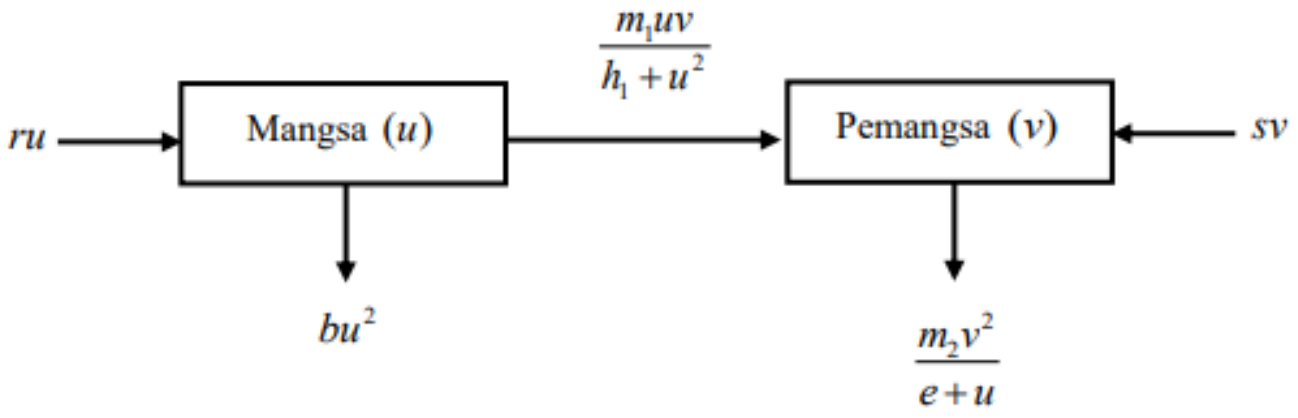

Gambar 2.1. Diagram Model Mangsa Pemangsa

Dari Gambar 2.1., terlihat bahwa laju perubahan kepadatan populasi mangsa bergantung pada laju pertumbuhan intrinsik mangsa $(r)$ dikurangi laju kompetisi diantara individu mangsa $(r)$ dan laju interaksinya dengan pemangsa. Bentuk interaksi tersebut merupakan pengembangan dari model yang dikembangkan dalam penelitian Alaoui dan Okiye [1] dimana dalam penelitian ini interaksi antara populasi mangsa dan pemangsa digambarkan menggunakan bentuk sederhana dari fungsi respon Holling tipe IV.

Selanjutnya, laju perubahan kepadatan populasi pemangsa bergantung pada laju pertumbuhan intrinsik pemangsa $(s)$ dikurangi laju kompetisi diantara individu pemangsa untuk memperoleh mangsa. Bentuk $-\frac{m_{2} v^{2}}{u}$ mengukur pengurangan pada populasi pemangsa karena adanya kompetisi diantara individu pemangsa untuk memperoleh mangsa ketika terjadi kelangkaan pada mangsa favoritnya. Adapun tambahan konstanta positif $e$ dalam penyebut untuk menormalkan residual penurunan pada populasi pemangsa ketika mangsa favoritnya yang tersedia terbatas. Konstanta $e$ tersebut merupakan populasi lain yang dapat dikonsumsi oleh pemangsa ketika mangsa yang tersedia tidak melimpah. Hal ini berarti bahwa dalam kasus 


\section{Jurnal Matematika, Statistika \& Komputasi}

\section{Nur Suci Ramadhani, Syamsuddin Toaha, Kasbawati}

kelangkaan yang parah, populasi pemangsa dapat beralih ke populasi lain tetapi pertumbuhannya akan terbatas karena kelangkaan mangsa favoritnya. Berdasarkan uraian di atas, diberikan model matematika yang ditulis dalam bentuk persamaan differensial sebagai berikut:

$$
\begin{aligned}
& \frac{d u}{d t}=r u-b u^{2}-\frac{m_{1} u v}{h_{1}+u^{2}}, \\
& \frac{d v}{d t}=s v-\frac{m_{2} v^{2}}{e+u} .
\end{aligned}
$$

Diasumsikan bahwa kondisi awal memenuhi $u(x, 0)>0, v(x, 0)>0$.

Keterangan variabel dan parameter pada Model (2.1) disajikan dalam Tabel 2.1.

\begin{tabular}{|c|c|c|}
\hline Simbol & Keterangan & Dimensi \\
\hline$u$ & Kepadatan populasi mangsa & Ekor \\
\hline$v$ & Kepadatan populasi pemangsa & Ekor \\
\hline$t$ & Waktu & Per hari \\
\hline$r$ & Laju pertumbuhan intrinsik mangsa & Per hari \\
\hline$s$ & Laju pertumbuhan intrinsik pemangsa & Per hari \\
\hline$b$ & Kekuatan kompetisi diantara individu mangsa & Per hari \\
\hline$m_{1}$ & $\begin{array}{l}\text { Nilai maksimum dimana laju pengurangan per } \\
\text { kapita mangsa dapat dicapai }\end{array}$ & Per hari \\
\hline$m_{2}$ & $\begin{array}{l}\text { Nilai maksimum pengurangan populasi pemangsa } \\
\text { karena kompetisi antar individu untuk memperoleh } \\
\text { mangsa }\end{array}$ & Per hari \\
\hline$h_{1}$ & Titik kejenuhan pemangsa & Ekor \\
\hline$e$ & Residual pengurangan pada populasi pemangsa & Ekor \\
\hline
\end{tabular}

Tabel 2.1. Deskripsi Variabel dan Parameter Model (2.1)

\section{Analisis Dinamik}

Titik kesetimbangan dari Sistem (2.1) diperoleh dengan menyelesaikan sistem persamaan berikut:

$$
\begin{aligned}
& \frac{d u}{d t}=r u-b u^{2}-\frac{m_{1} u v}{h_{1}+u^{2}}=0, \\
& \frac{d v}{d t}=s v-\frac{m_{2} v^{2}}{e+u}=0 .
\end{aligned}
$$

Jika Persamaan (2.2) dan (2.3) diselesaikan maka diperoleh empat titik kesetimbangan sebagai berikut:

1. Titik kesetimbangan populasi mangsa dan pemangsa punah yaitu $T_{1}=(0,0)$

2. Titik kesetimbangan populasi mangsa punah yaitu $T_{2}=\left(0, \frac{s e}{m_{2}}\right)$ 


\section{Jurnal Matematika, Statistika \& Komputasi}

\section{Nur Suci Ramadhani, Syamsuddin Toaha, Kasbawati}

3. Titik kesetimbangan populasi pemangsa punah yaitu $T_{3}=\left(\frac{r}{b}, 0\right)$

4. Titik kesetimbangan populasi mangsa dan pemangsa bertahan hidup yaitu $T_{4}=(\bar{u}, \bar{v})$,

$$
\begin{aligned}
\text { dengan } \bar{v}= & \frac{s(e+\bar{u})}{m_{2}} \text { dan } \bar{u} \text { adalah akar positif dari persamaan kubik } \\
& u^{3}-\frac{r}{b} u^{2}+\left(\frac{h_{1} b m_{2}+m_{1} s}{b m_{2}}\right) u+\frac{m_{1} s e-r h_{1} m_{2}}{b m_{2}}=0
\end{aligned}
$$

dimana $b \neq 0, m_{2} \neq 0$. Selanjutnya untuk menentukan akar-akar real positif dari persamaan (2.4) digunakan aturan tanda Descartes'. Berdasarkan aturan tanda Descartes', diperoleh akar-akar real positif dari persamaan (2.4) sebagai berikut:

a. Jika $m_{1} s e-r h_{1} m_{2}=0$ maka terdapat dua atau tidak ada akar positif $\bar{u}$.

b. Jika $m_{1} s e-r h_{1} m_{2}<0$ maka terdapat satu atau tiga akar positif $\bar{u}$.

c. Jika $m_{1} s e-r h_{1} m_{2}>0$ maka terdapat dua atau tidak ada akar positif $\bar{u}$.

Dari ketiga kondisi di atas, untuk memastikan bahwa Persamaan (2.4) memiliki akar real positif paling sedikit satu maka syarat yang harus dipenuhi yaitu $m_{1} s e-r h_{1} m_{2}<0$. Berdasarkan hal tersebut, titik kesetimbangan positif $T_{4}=(\bar{u}, \bar{v})$ ada jika memenuhi syarat $m_{1} s e<r h_{1} m_{2}$ dengan $\bar{v}=\frac{s(e+\bar{u})}{m_{2}}$ dan $\bar{u}$ adalah akar positif dari Persamaan (2.4). Selanjutnya analisis kestabilan lokal pada setiap titik kesetimbangan pada Sistem (2.1) disajikan dalam Teorema 2.1.

\section{Teorema 2.1.}

1. Titik kesetimbangan $T_{1}=(0,0)$ bersifat node tidak stabil.

2. Titik kesetimbangan $T_{2}=\left(0, \frac{\text { se }}{m_{2}}\right)$ bersifat stabil asimtotik lokal jika $r<\frac{m_{1} s e}{h_{1} m_{2}}$.

3. Titik kesetimbangan $T_{3}=\left(\frac{r}{b}, 0\right)$ bersifat tidak stabil pelana.

4. Titik kesetimbangan $T_{4}=(\bar{u}, \bar{v})$ bersifat stabil asimtotik lokal jika

$$
(2 b \bar{u}+s) \alpha^{2}+m_{1} h_{1} \bar{v}>r \alpha^{2}+m_{1} \overline{v u}^{2}
$$

dan

$$
m_{1} m_{2} \overline{u v}^{2} \alpha>s \gamma^{2}\left[(r-2 b \bar{u}) \alpha^{2}-m_{1} \beta \bar{v}\right]
$$

dengan $\alpha=\left(h_{1}+u^{2}\right), \beta=\left(h_{1}-u^{2}\right), \gamma=(e+u)$.

\section{Bukti.}




\section{Jumal Matematika, Statistika \& Komputasi}

\section{Nur Suci Ramadhani, Syamsuddin Toaha, Kasbawati}

1. Matriks Jacobian dari Sistem (2.1) pada titik kesetimbangan $T_{1}$ adalah

$$
J\left(T_{1}\right)=\left[\begin{array}{ll}
r & 0 \\
0 & s
\end{array}\right],
$$

dari matriks $J\left(T_{1}\right)$ diperoleh nilai eigen $\lambda_{1}=r>0$ dan $\lambda_{2}=s>0$. Karena kedua nilai eigen dari $J\left(T_{1}\right)$ adalah positif, maka $T_{1}$ tidak stabil.

2. Matriks Jacobian dari Sistem (2.1) pada titik kesetimbangan $T_{2}$ adalah

$$
J\left(T_{2}\right)=\left\{\begin{array}{cc}
r-\frac{m_{1} s e}{h_{1} m_{2}} & 0 \\
\frac{s^{2}}{m_{2}} & -s
\end{array}\right],
$$

dari matriks $J\left(T_{2}\right)$ diperoleh nilai eigen $\lambda_{1}=r-\frac{m_{1} s e}{h_{1} m_{2}}$ dan $\lambda_{2}=-s<0 \quad$ sehingga titik kesetimbangan $T_{2}$ stabil jika $r<\frac{m_{1} s e}{h_{1} m_{2}}$.

3. Matriks Jacobian dari Sistem (2.1) pada titik kesetimbangan $T_{3}$ adalah

$$
J\left(T_{3}\right)=\left\{\begin{array}{cc}
-r & -\frac{r b m_{1}}{r^{2}+h_{1} b^{2}} \\
0 & s
\end{array}\right],
$$

dari matriks $J\left(T_{3}\right)$ diperoleh nilai eigen $\lambda_{1}=-r<0$ dan $\lambda_{2}=s>0$ sehingga titik kesetimbangan $T_{3}$ tidak stabil pelana.

4. Matriks Jacobian dari Sistem (2.1) pada titik kesetimbangan $T_{4}$ diberikan sebagai berikut.

$$
J\left(T_{4}\right)=\left[\begin{array}{ll}
j_{1} & j_{2} \\
j_{3} & j_{4}
\end{array}\right],
$$

dengan,

$j_{1}=r-2 b \bar{u}-\frac{m_{1} \bar{v}\left(h_{1}-\bar{u}^{2}\right)}{\left(h_{1}+\bar{u}^{2}\right)^{2}}, j_{2}=-\frac{m_{1} \bar{u}}{h_{1}+\bar{u}^{2}}<0, j_{3}=\frac{m_{2} \bar{v}^{2}}{(e+\bar{u})^{2}}>0, j_{4}=-s<0$.

Dari matriks tersebut diperoleh trace dan determinant dari $J\left(T_{4}\right)$ sebagai berikut

$$
\begin{aligned}
& \operatorname{trace}\left(J\left(T_{4}\right)\right)=r-2 b \bar{u}-s-\frac{m_{1} \bar{v}\left(h_{1}-\bar{u}^{2}\right)}{\left(h_{1}+\bar{u}^{2}\right)^{2}}, \\
& \operatorname{det}\left(J\left(T_{4}\right)\right)=\left(r-2 b \bar{u}-\frac{m_{1} \bar{v}\left(h_{1}-\bar{u}^{2}\right)}{\left(h_{1}+\bar{u}^{2}\right)^{2}}\right)(-s)+\left(\frac{m_{1} m_{2} \overline{u v}^{2}}{\left(h_{1}+\bar{u}^{2}\right)(e+\bar{u})^{2}}\right) .
\end{aligned}
$$




\section{Jurnal Matematika, Statistika \& Komputasi}

\section{Nur Suci Ramadhani, Syamsuddin Toaha, Kasbawati}

Titik kesetimbangan $T_{4}$ stabil asimtotik lokal jika trace $\left(J\left(T_{4}\right)\right)<0 \operatorname{dan} \operatorname{det}\left(J\left(T_{4}\right)\right)>0$ yang ekuivalen dengan kondisi (2.5) dan (2.6).

Dari keempat titik kesetimbangan tersebut, kondisi yang diharapkan secara ekologi adalah kedua populasi dapat bertahan hidup dan tidak ada populasi yang punah sehingga titik kesetimbangan yang menarik untuk dikaji adalah titik kesetimbangan $T_{4}$. Berdasarkan hal tersebut, pada bagian selanjutnya akan ditunjukkan simulasi numerik dari model (2.1) menggunakan parameter-parameter model yang memenuhi syarat titik kesetimbangan $T_{4}$ stabil asimtotik secara lokal.

\section{Solusi Numerik}

Tujuan dari simulasi ini untuk menunjukkan kestabilan dari titik kesetimbangan $T_{4}$ dan perilaku dari kedua populasi mangsa dan pemangsa ketika saling berinteraksi. Dalam simulasi ini diasumsikan beberapa nilai parameter yang memenuhi syarat kestabilan titik kesetimbangan $T_{4}$ yang diberikan sebagai berikut

$$
r=0.5, s=0.35, b=0.09, m_{1}=0.7, m_{2}=0.5, h_{1}=7 \text {, dan } e=5 .
$$

Dari parameter-parameter tersebut ditemukan bahwa $m_{1} s e<r h_{1} m_{2}$ sehingga Persamaan (2.4) memiliki satu akar real positif yaitu $T_{4}=(\bar{u}, \bar{v})=(2.4,5.2)$. Selanjutnya dari proses perhitungan, diperoleh nilai trace $\left(J\left(T_{4}\right)\right)=-0.30918<0$ dan $\operatorname{det}\left(J\left(T_{4}\right)\right)=0.01796>0$ atau nilai eigen $\lambda_{1}=-0.078$ dan $\lambda_{2}=-0.232$ yang menunjukkan bahwa nilai parameter tersebut memenuhi syarat titik kesetimbangan $T_{4}$ stabil asimtotik secara lokal. Dari hasil simulasi yang dilakukan diperoleh grafik solusi numerik model yang dapat dilihat dalam Gambar 4.1.

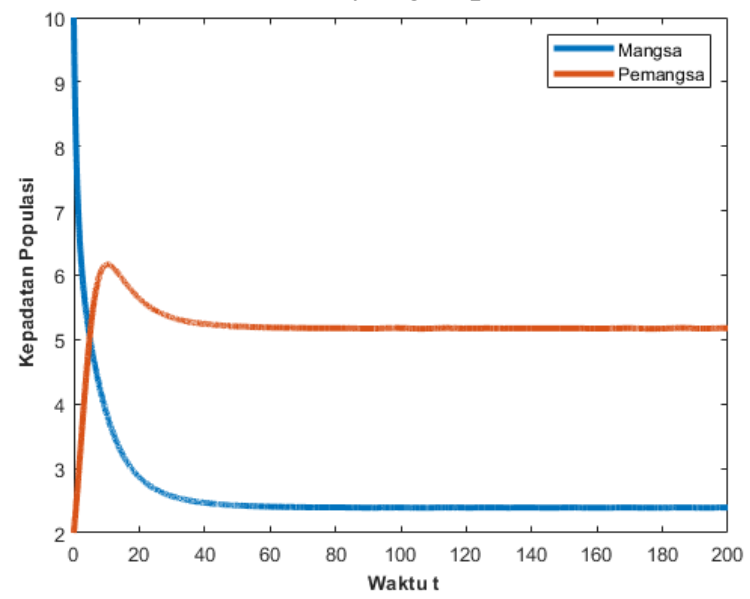

(a) 


\section{Jurnal Matematika, Statistika E Komputasi}

\section{Nur Suci Ramadhani, Syamsuddin Toaha, Kasbawati}

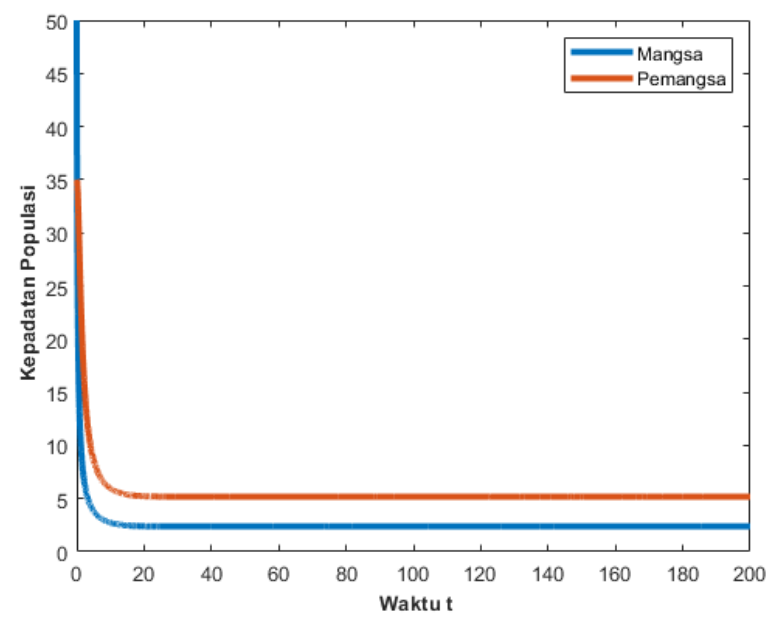

(b)

Gambar 4.1. Grafik Solusi Populasi Mangsa (u) dan Pemangsa (v) dengan Kondisi Awal (a)

$$
(u(0), v(0))=(10,2) \text { dan (b) }(u(0), v(0))=(35,50) \text {. }
$$

Gambar 4.1 menunjukkan bahwa dengan kondisi awal yang berbeda, grafik solusi menunjukkan perilaku yang sama yaitu bergerak dari kondisi awal kemudian solusi konvergen ke titik kesetimbangan $T_{4}=(\bar{u}, \bar{v})=(2.4,5.2)$. Kekonvergenan tersebut berarti bahwa kepadatan kedua populasi mangsa dan pemangsa tidak akan pernah punah pada saat waktu $t$ semakin membesar. Selanjutnya, perilaku dari kedua populasi ketika saling berinteraksi dapat dilihat dalam Gambar 4.2.

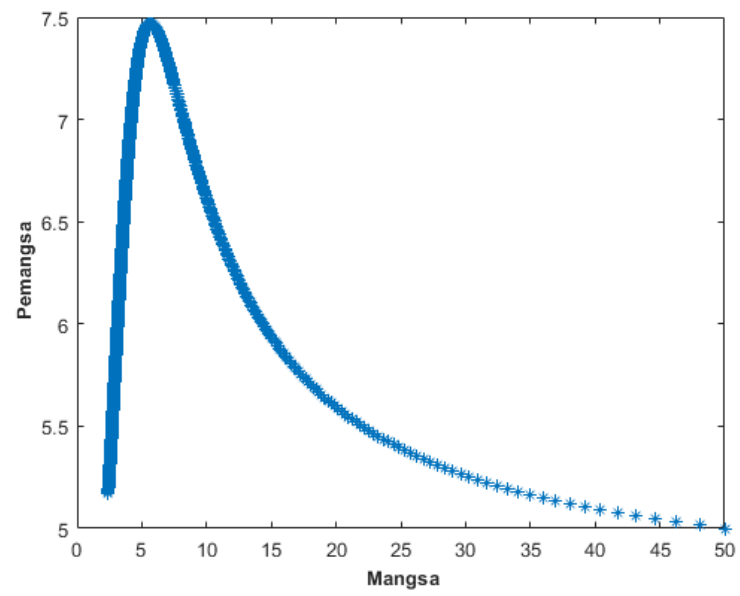

Gambar 4.2. Grafik Solusi Perilaku dari Kedua Populasi Mangsa (u) dan Pemangsa (v)

$$
\text { dengan nilai awal }(u(0), v(0))=(50,5)
$$

Dari grafik tersebut dapat dilihat bahwa ketika jumlah populasi mangsa kurang padat maka terjadi peningkatan pada jumlah populasi pemangsa. Hal yang menarik terjadi pada saat jumlah populasi mangsa lebih besar dari 6 , saat populasi mangsa semakin meningkat terjadi penurunan terhadap jumlah populasi pemangsa dan ketika waktu diperpanjang maka jumlah populasi pemangsa akan konvergen di sekitar nilai awal. Hal ini menunjukkan perilaku dari populasi 


\section{Jurnal Matematika, Statistika \& Komputasi}

\section{Nur Suci Ramadhani, Syamsuddin Toaha, Kasbawati}

mangsa berbahaya yang digambarkan menggunakan fungsi respon Holling tipe IV yang mana ketika populasi mangsa semakin padat maka laju predasi dari pemangsa berkurang karena adanya sifat bertahan dari populasi mangsa ketika jumlahnya cukup besar.

\section{Kesimpulan}

Dalam penelitian ini digunakan modifikasi model Leslie-Gower dan menggunakan bentuk sederhana dari fungsi respon Holling tipe IV untuk menggambarkan total individu mangsa yang dikonsumsi oleh pemangsa. Dari hasil analisis, ditemukan syarat titik kesetimbangan kedua populasi dapat bertahan hidup $\left(\mathrm{T}_{4}\right)$ stabil asimtotik lokal. Dari hasil simulasi yang dilakukan terlihat bahwa dengan menggunakan nilai parameter yang memenuhi salah satu syarat titik kesetimbangan $\mathrm{T}_{4}$ stabil asimtotik lokal, diperoleh hasil bahwa kepadatan kedua populasi mangsa dan pemangsa tidak akan punah pada saat waktu $t$ semakin membesar. Selanjutnya, ketika populasi mangsa semakin padat dan memiliki kemampuan yang lebih baik dalam mempertahankan diri maka populasi pemangsa dapat beralih ke populasi lain untuk bertahan hidup tetapi pertumbuhannya akan terbatas karena mangsa favoritnya terbatas. Hasil simulasi juga menunjukkan bahwa pada saat kepadatan populasi mangsa meningkat terjadi penurunan terhadap kepadatan populasi pemangsa karena populasi mangsa yang berbahaya memiliki kemampuan yang lebih baik untuk mempertahankan diri dari pemangsa ketika jumlahnya cukup besar.

\section{Daftar Pustaka}

[1] Alaoui, M. A. \& Okiye D., 2003. Boundedness and Global Stability for a Predator-Prey Model with Modified Leslie-Gower and Holling-Type II Schemes. Applied Mathematics Letter, 1069 - 1075.

[2] Alaoui, M. A., 2002. Study of a Leslie-Gower Type Tritrophic Population. Chaos Soliton Fract, Vol. 2002, No. $14,1275-1293$.

[3] Andrews, J. A., 1968. The Effect of Enrichment of Three Species Food Chain with Nonlinear Functional Response. Biotechnology and Bioengineering, Vol. 10, No. 6, 707 723.

[4] Chen L. \& Chen F., 2009. Global Stability of a Leslie-Gower Model with Feedback Controls. Applied Mathematics Letters, Vol. 22, No. 9, 1330 - 1334.

[5] Feng P.\& Kang Y., 2015. Dynamics of a Modified Leslie-Gower Model with Double Allee Effects. Nonlinear Dynamics, 80: 1051 - 1062.

[6] Huang J., Xiaojing X. \& Xinan Z., 2016. Bifurcation of Codimension 3 in a Predator-Prey System of Leslie Type with Simplified Holling Type IV Functional Response. International Jurnal of Bifurcation and Chaos, Vol. 26, No. 2, 1650034 - 11.

[7] Huang, To, Huayong Z., Zhengran H., Ge P., Shengnan M., Xiumin Z. \& Zichun G., 2019. Predator-Prey Pattern Formation Driven by Population Diffusion Based on Moore Neighborhood Structure. Advances in Difference Equation, 399. 


\section{Jurnal Matematika, Statistika \& Komputasi}

\section{Nur Suci Ramadhani, Syamsuddin Toaha, Kasbawati}

[8] Khajanchi S., 2017. Modeling the Dynamics of Stage-Structure Predator-Prey System with Monod-Haldane Type Response Function. Applied Mathematics and Computations, 302: $122-143$.

[9] Liu M. \& Wang K. 2013. Dynamics of a Leslie-Gower Holling Type II Predator-Prey System with Levy Jumps. Nonlinear Analysis: Theory, Methods \& Applications, Vol 85, $204-213$.

[10] Ruan, S. dan Dongmei X., 2001. Global Analysis in A Predator-Prey System with Nonmonotonic Functional Response. SIAM J. APPL. MATH, Vol. 61, No. 4, 1445 -1472.

[11] Shen, C., 2007. Permanence and Global Attractivity of Food-Chain System with Holling IV Type Functional Response. Applied Mathematics and Computations, 194: 179 - 185.

[12] Siddik, A. M. A., dkk. 2021. Stability analysis of Prey-Predator Model with Holling Type IV Functional Response and Infectious Predator. Jurnal Matematika, Statistika \& Komputasi, Vol. 17, No. 2, 155 - 165.

[13] Sokol, W. \& Howel, J. A., 1987. The Kinetics of Phenol Oxidation by Washed Cells. Biotechnology and Bioengineering, 30: 921 - 927.

[14] Song, J., dkk. 2019. A Non-Autonomous Leslie-Gower Model with Holling Type IV Functional Response and Harvesting Complexity. Advances in Difference Equation, 2019: 299.

[15] Xu D., Liu M. \& Xu X., 2020. Analysis of Stochastic Predator-Prey System with Modified Leslie-Gower Model and Holling Type IV Schemes. Physica A, Vol. 2020, No. 537, 122761 .

[16] Yu S., 2014. Global Stability of a Modified Leslie-Gower Model with BeddingtonDeAngelis Functional Response. Advances in Difference Equation, 2014: 84.

[17] Yusrianto, dkk. 2019. Analisis Kestabilan Model Mangsa Pemangsa dengan Pemanenan Ambang Batas pada Populasi Pemangsa. Jurnal Matematika, Statistika \& Komputasi, Vol. 16, No. 1, $97-106$.

[18] Yue Q., 2016. Dynamics of Modified Leslie-Gower Model Predator-Prey Model with Holling Type II Schemes and a Prey Refuge. Springer Plus, 5: 461.

[19] Zhang Z., Upadhyay R. K. \& Datta J., 2018. Bifurcation Analysis of a Modified LeslieGower Model with Holling Type IV Functional Response and Nonlinear Prey Harvesting. Advances in Difference Equation, 2018: 127. 